\title{
IMPLEMENTASI KEBIJAKSANAAN REFORMASI BIROKRASI DALAM PENGUATAN APARATUR SIPIL NEGARA DI KEMENTERIAN AGAMA REPUBLIK INDONESIA
}

\author{
Oleh \\ $\mathbf{U} \mathbf{c} \mathbf{u}$ \\ Staf Kementerian Agama \\ Mahasiswa Program Pascasarjana Magister Terapan Ilmu Pemerintahan IPDN \\ ucudepag@gmail.com
}

\begin{abstract}
Rureaucracy reform in Ministry of Religion, Republic of Indonesia is the most important aspect to be implemented immediately. It is done for increasing the quality of public service as the shape of good governance which is suitable with national bureaucracy reform policy.

This research is using qualitative approach with descriptive research type. Research informant is determined with purposive sampling technique and snowball sampling technique. Data collecting technique is using interview with key informant, observation and literature study. Besides that, data analysis technique is using data reduction, data display and concluding technique.

Research result concluding namely 1) the implementation of bureaucracy reform policy in strengthening of state civil apparatus is done well which is seen with the agent of change role for influencing other employees. Beside that, the succession of bureaucracy reform policy in Ministry of Religion Republic of Indonesia can be seen from several aspects, namely policy standard and purpose, the characteristic of the policy implementer, implementer disposition, inter-organizational relation, organizational resources, and also social, economic and politics aspects. 2) the obstacles in implementation of bureaucracy reform policy for strengthening state civil apparatus in Ministry of Religion Republic of Indonesia can be seen from several aspects, namely team work weaknesses, resistance of status quo bureaucracy. 3) Acceleration model of bureaucracy reform policy for strengthening state civil apparatus in Ministry of Religion Republic of Indonesia is adopting RELIGI strategy. RELIGI is an acronym of Reward and Punishment, Empathy, Leadership, Intuition, Group Working and Interdependence.
\end{abstract}

Keywords: policy implementation, bureaucracy reform, state civil apparatus

\begin{abstract}
Abstrak
$\mathrm{R}$ eformasi Birokrasi di lingkup Kementerian Agama Republik Indonesia menjadi aspek yang segera harus diimplementasikan. Hal ini dilakukan untuk meningkatkan kualitas pelayanan kepada masyarakat sebagai perwujudan tata kelola pemerintahan yang baik sesuai dengan arah dan kebijakan reformasi secara nasional.

Penelitian ini menggunakan desain penelitian kualitatif dengan tipe penelitian deskriptif. Adapun informan penelitian ditentukan dengan menggunakan teknik purposive sampling bagi pihak-pihak yang kompeten untuk memberikan keterangan akurat terkait permasalahan,
\end{abstract}


sementara teknik bola salju (snowball sampling) digunakan pada objek kebijakan yang memperoleh dampak. Wawancara, Observasi dan Studi Kepustakaan menjadi teknik yang digunakan dalam mengumpulkan data sementara reduksi data, penyajian data dan penarikan simpulan menjadi teknis analisis data kualitatif yang digunakan dalam penelitian ini.

Adapun hasil penelitian ini adalah 1) Implementasi Kebijakan Reformasi Birokrasi dalam Penguatan Aparatur Sipil Negara telah berjalan dengan baik sebagaimana terlihat dengan adanya peran agen perubahan sebagai influence actor bagi ASN lainnya. Berjalannya Implementasi Kebijakan Reformasi Birokrasi di Kementerian Agama Republik Indonesia dapat dilihat dari aspek standar dan tujuan, sumber daya, hubungan antar- organisasi, karakteristik agen pelaksana, disposisi implementor serta aspek sosial, ekonomi dan politik. 2) Hambatan yang ditemukan dalam Implementasi Kebijakan Refomasi Birokrasi dalam Penguatan Aparatur Sipil Negara di Kementerian Agama Republik Indonesia berupa lemahnya tim kerja (team work), penentangan (resistensi) dari dalam birokrasi itu sendiri. 3) Model akselerasi implementasi kebijakan reformasi birokrasi dalam penguatan ASN di Kementerian Agama Republik Indonesia adalah dengan mengadaptasi RELIGI (Reward and Punishment, Empathy, Leadership, Intuition, Group Working, and Interdependence).

Kata kunci: implementasi kebijaksanaan, reformasi birokrasi, aparatur sipil negara

\section{PENDAHULUAN}

$\mathrm{U}$ paya Kementerian Agama saat ini telah dan sedang melaksanakan program reformasi birokrasi dengan menitikberatkan perbaikan pada bidang penataan organisasi, sistem ketatalaksanaan, sumber daya manusia dan struktur penggajian (remunerasi). Dalam menjalankan reformasi birokrasi Kementerian Agama membutuhkan seorang pemimpin yang profesional dan handal serta mampu bersinergi dengan kementerian-kementerian lain dan mampu menjalankan tugas dan fungsinya dalam mewujudkan pemerintahan yang baik. Hal itu didasarkan pada Keputusan Menteri Agama Nomor 153 Tahun 2009, tentang Reformasi Birokrasi Kementerian Agama. Tujuan Reformasi Birokrasi pada Kementerian Agama adalah:

a. Menciptakan aparatur Kementerian Agama yang bersih, profesional, dan bertanggung jawab.

b. Menciptakan birokrasi di Kementerian Agama yang efisien dan efektif sehingga dapat memberikan pelayanan publik yang optimal.
Pelaksanaan good governance (Asas Umum Penyelenggaraan Negara sebagaimana dimaksud dalam Undang-Undang Nomor 28 Tahun 1999 tentang Penyelenggaraan Negara yang Bersih dan Bebas dari Korupsi, Kolusi dan Nepotisme); Asas Kepastian Hukum, Asas Tertib Penyelenggaraan Negara, Asas Kepentingan Umum, Asas Keterbukaan, Asas Proporsionalitas dan Asas Akuntabilitas. Namun hal itu dalam kenyataan belum dilaksanakan dengan optimal.

Kepemimpinan merupakan landasan yang penting dalam meningkatkan kinerja Aparatur Sipil Negara, pemimpin sebagai tolok ukur keberhasilan, jika kepemimpinan berkualitas, profesional, maka Aparatur Sipil Negara Kementerian Agama akan berkualitas pula, tetapi sebaliknya jika pemimpinnya kurang berkualitas maka kinerja Aparatur Sipil Negara di Kantor Kementerian Agama tidak akan berjalan dengan baik. Dari itu, terlihat bahwa pemimpin merupakan salah satu faktor yang menentukan keberhasilan dan kelangsungan Aparatur Sipil Negara, begitu juga halnya di Kementerian Agama, kuat tidaknya kepemimpinan, kegagalan dan keberhasilan kepemimpinan, banyak ditentukan oleh sosok pemimpin karena pemimpin merupakan pengendali penentu arah yang ditempuh menuju tujuan yang 
hendak dicapai yaitu pemerintahan yang baik.

Pemimpin perlu memadukan beberapa konsep agar kepemimpinan yang ideal dapat terwujud. Gaya dan perilaku pemimpin yang positif dan cukup ideal dapat mendorong Aparatur Sipil Negara dalam mengarahkan dan memotivasi individu Aparatur Sipil Negara (ASN) untuk bekerja sama dalam mewujudkan tujuan pemerintahan yang baik di Kementerian Agama.

Dengan harapan hasil yang telah diperoleh dari pelaksanaan reformasi birokrasi pada periode 2010-2014, menjadi dasar bagi pelaksanaan reformasi birokrasi pada tahapan selanjutnya (2015-2019). Karena itu, pelaksanaan reformasi birokrasi 2015-2019, merupakan penguatan dari pelaksanaan reformasi birokrasi tahapan sebelumnya di Kementerian Agama.

\section{IDENTIFIKASI MASALAH}

Berdasarkan latar belakang yang telah diuraikan di atas, maka identifikasi masalah yang muncul adalah masih belum optimalnya pelaksanaan Implementasi Kebijaksanaan Reformasi Birokrasi dalam Penguatan Aparatur Sipil Negara di Kantor Kementerian Agama Republik Indonesia.

\section{BATASAN Masalah}

Berdasarkan latar belakang masalah di atas, maka yang menjadi Batasan masalah dalam penelitian ini pada aspek, konsep dasar, model, stategi, proses dan hambatan adalah Implementasi Kebijaksanaan Reformasi Birokrasi dalam Penguatan Aparatur Sipil Negara di Kantor Kementerian Agama Republik Indonesia.

\section{Perumusan Masalah}

Berdasarkan latar belakang masalah di atas, maka yang menjadi rumusan masalah dalam penelitian ini adalah Model Implementasi Kebijaksanaan Reformasi Birokrasi dalam Penguatan Aparatur Sipil
Negara di Kantor Kementerian Agama Republik Indonesia.

\section{Tujuan Penelitian}

Tujuan penelitian ini adalah untuk menganalisis dan mengonstruksi model implementasi kebijaksanaan reformasi birokrasi dalam penguatan Aparatur Sipil Negara pada Kantor Kementerian Agama Republik Indonesia.

\section{Kerangka Pemikiran}

Kepemimpinan pada dasarnya adalah proses memengaruhi orang lain. Selain itu kepemimpinan juga berarti kemampuan untuk memengaruhi, menggerakkan, dan mengarahkan suatu tindakan pada diri seseorang atau sekelompok orang untuk tujuan tertentu. Dalam upaya memengaruhi tersebut seorang pemimpin menerapkan gaya yang berbeda-beda. Substansi penelitian ini mengangkat gaya kepemimpinan yang dikemukakan Bass (1990: 22), yaitu gaya kepemimpinan transformasional dan transaksional. Dalam penelitian ini, dapat penulis uraian kerangka pemikiran penelitian ini sebagai berikut.

Keputusan Menteri Agama (KMA) terjadi overlav, aturan/regulasi tertentu apabila melakukan tindakan, perubahan atau kreativitas yang reformatif tidak bisa berjalan karena tidak ada aturannya, padahal aturan yang dibuat terkadang tidak jelas dan tidak rasional dengan tetap diikutinya.

a. Kontra produktifnilailama dan nilaibaru, kepemimpinan birokrasi bersumber pada nilai-nilai lama sementara organisasi bersumber pada nilai-nilai baru, dan birokrasi ditempatkan sebagai organisasi yang sangat tertutup dan elitis tidak semua orang bisa mengakses ke dalam, kalaupun mencoba masuk akan dihadang serangkaian prosedur yang mengada-ada, birokrasi ditempatkan sebagai suatu organisasi yang tidak bisa dipengaruhi tetapi dia memengaruhi. 
Untuk lebih jelasnya, secara sistematis kerangka pemikiran terdapat pada gambar sebagai berikut.

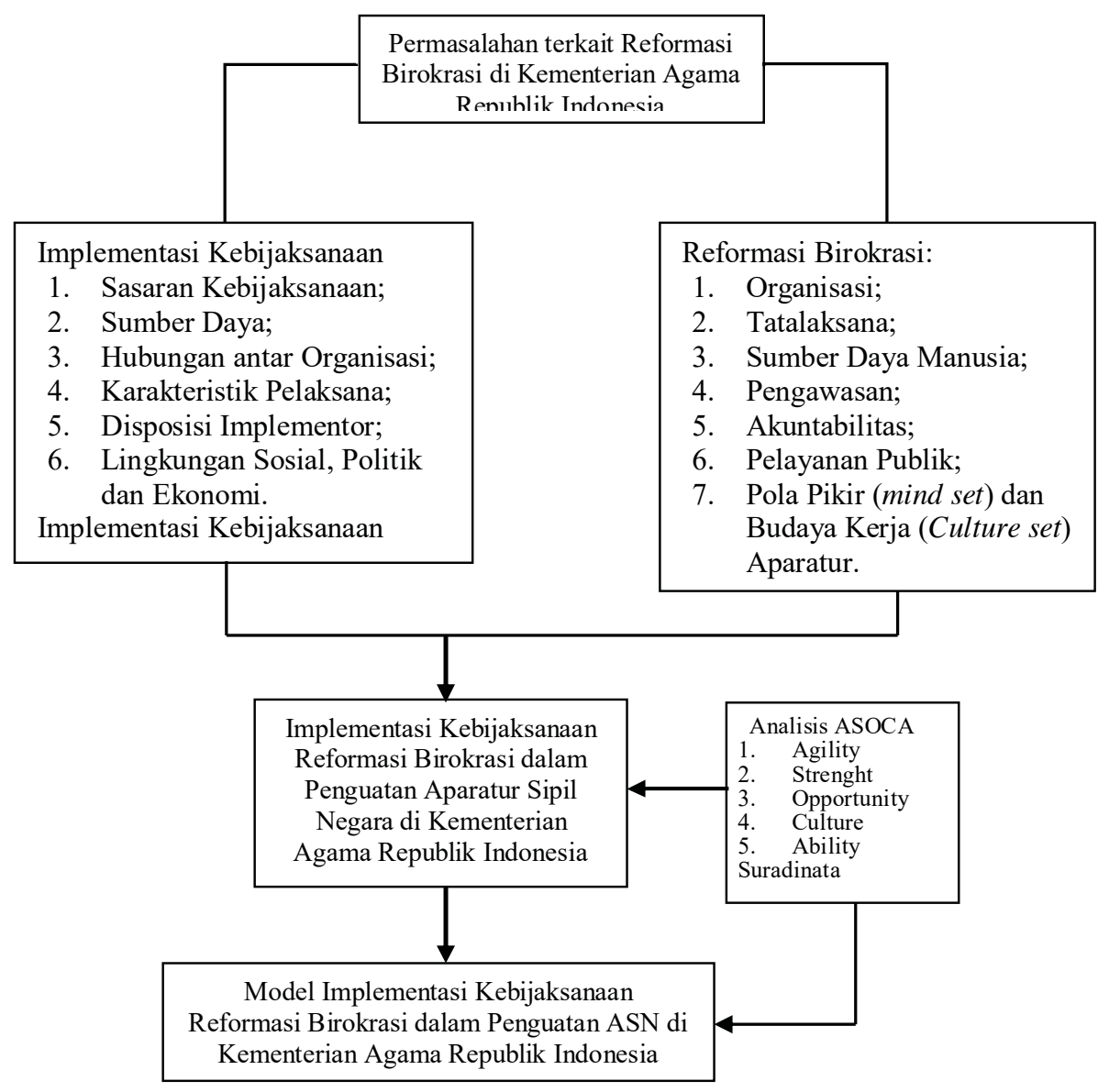

Kerangka Pemikiran

1. Birokrasi sangat memegang teguh prosedur yang dibuat sedemikian ditujukan supaya orang tidak mudah mendapatkan, walaupun tujuannya untuk kehati-hatian dan tertib administratif. Namun hal tersebut menimbulkan birokratisme, sesuatu urusan tidak bisa selesai oleh satu meja, tetapi harus melalui beberapa meja dan melalui jenjang atau hierarki yang berurut.

Penguatan ASN membutuhkan komitmen penyelenggaraan negara untuk itu perlu dilakukan secara konsisten atau tidak transparannya antara pejabat negara dan institusinya.
2. Kualitas sumber daya manusia aparatur yang masih lemah disebabkan dalam proses rekruitmen tidak selektif, maupun pembinaan atau pengembangannya yang tidak berdasarkan pada dasardasar profesionalisme dan kepentingan jangka panjang, sehingga implementasi kesediaan sumber daya aparatur yang kurang memadai.

3. Sistem pengawasan yang masih lemah yang lebih menitiberatkan pada laporan administratif, tidak pada output atau kualitas dari pada output bahkan tidak memperhatikan outcome dan benefit yang dihasilkan. 


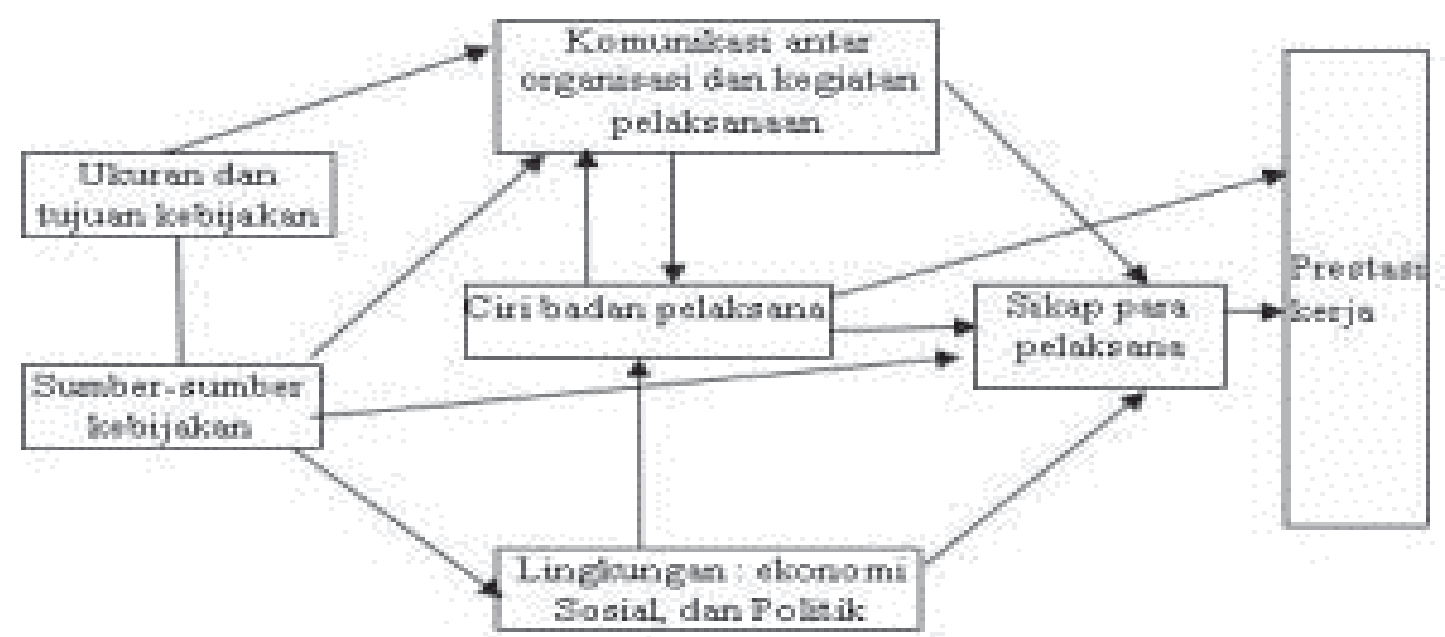

Model Implementasi Kebijaksanaan Van Meter dan Van Horn

Berdasarkan kerangka pemikiran tersebut maka Van Meter dan Van Horn (Budi Winarno,2002: 102), membatasi implementasi kebijaksanaan sebagai berikut. "...Implementasi kebijaksanaan sebagai tindakan-tindakan yang dilakukan individu-individu (kelompok-kelompok) pemerintah maupun swasta yang diarahkan untuk mencapai tujuan-tujuan yang telah ditetapkan dalam keputusan-keputusan sebelumnya.

Meter dan dan Van Horn (Subarsono,2006: 99), mengemukakan bahwa ada enam variabel yang memengaruhi kinerja implementasi. Keenam variabel tersebut, diilustrasikan secara sistematis sebagaimana gambar di atas.

Keenam variabel tersebut, dijelaskan Subarsono, (2006: 99), sebagai berikut.

\section{1) Standar dan sasaran kebijaksanaan.}

Setiap kebijaksanaan publik harus mempunyai standar dan suatu sasaran kebijaksanaan jelas dan terukur. Dengan ketentuan tersebut tujuannya dapat terwujudkan. Dalam standar dan sasaran kebijaksanaan tidak jelas, sehingga tidak bias terjadi multi-interpretasi dan mudah menimbulkan kesalahpahaman dan konflik antara agen implementasi.

2) Sumber daya.

Dalam suatu implementasi kebijaksanaan perlu dukungan sumber daya, baik sumber daya manusia (human resources) maupun sumber daya materi (material resources) dan sumber daya metode (methodresources). Dari ketiga sumber daya tersebut, yang paling penting adalah sumber daya manusia, karena disamping sebagai subjek implementasi kebijaksanaan juga termasuk objek kebijaksanaan publik.

\section{3) Hubungan antar- organisasi.}

Dalam banyak program implementasi kebijaksanaan, sebagai realitas dari program kebijaksanaan perlu hubungan yang baik antar- instansi yang terkait, yaitu dukungan komunikasi dan koordinasi. Untuk itu, diperlukan koordinasi dan kerja samaantar-instansibagikeberhasilan suatu program tersebut. Komunikasi dan koordinasi merupakan salah satu urat nadi dari sebuah organisasi agar program-programnya tersebut 
dapat direalisasikan dengan tujuan serta sasarannya.

4) Karakteristik agen pelaksana.

Dalamsuatuimplementasikebijaksanaan agar mencapai keberhasilan maksimal harus diidentifikasikan dan diketahui karakteristik agen pelaksana yang mencakup; struktur birokrasi, normanorma, dan pola-pola hubungan yang terjadi dalam birokrasi, semua itu akan memengaruhi implementasi suatu program kebijaksanaan yang telah ditentukan.

\section{5) Disposisi implementor.}

Dalam implementasi kebijaksanaan sikap atau disposisi implementor ini dibedakan menjadi tiga hal, yaitu; (a) respons implementor terhadap kebijaksanaan, yang terkait dengan kemauan implementor untuk melaksanakan kebijaksanaan publik; (b) kondisi, pemahaman terhadap kebijaksanaan yang telah ditetapkan; dan (c) intens disposisi implementor, yakni preferensi nilai yang dimiliki tersebut.

6) Kondisi lingkungan sosial, politik dan ekonomi.

Variabel ini mencakup sumber daya ekonomi lingkungan yang dapat mendukung keberhasilan implementasi kebijaksanaan, sejauh mana kelompokkelompok kepentingan memberikan dukungan bagi implementasi kebijaksanaan; karakteristik para partisipan, yakni mendukung atau menolak; bagaimana sifat opini publik yang ada di lingkungan dan apakah elite politik mendukung implementasi kebijaksanaan.

\section{METODE PENELITIAN}

Proses penelitian dalam penulisan ini berkaitan dengan pelaksanaan Implementasi Kebijaksanaan Reformasi
Birokrasi Dalam Penguatan Aparatur Sipil Negara di Kementerian Agama Republik Indonesia, oleh karena itu untuk mendapatkan jawaban mendalam mengenai permasalahan yang ada maka desain penelitian yang digunakan dalam penelitian ini, adalah desain penelitian kualitatif, menurut Creswell (2013: 23) bahwa "penelitian kualitatif sebagai suatu gambaran kompleks, meneliti katakata, laporan terinci dari pandangan responden, dan melakukan studi pada situasi yang alami".

Data dalam penelitian ini, berbagai peristiwa, informasi, jawaban yang berupa kata-kata dan tindakan orang-orang yang diamati atau yang diwawancara, merupakan jenis data utama. Keuntungan peneliti sebagai instrumen kunci adalah karena sifatnya yang responsif dan adaptable. Peneliti sebagai instrumen akan dapat menekankan pada keseluruhan objek, mengembangkan dasar pengetahuan, kesegeraan memproses dan mempunyai kesempatan untuk mengklarifikasi dan meringkas serta dapat memanfaatkan kesempatan untuk menyelidiki respons yang istimewa dan khas.

Sumber tertulis ini dapat dibagi atas sumber-sumber buku, majalah ilmiah, sumber data arsip, dokumen pribadi dan dokumen resmi. Kemudian jenis data dalam bentuk foto yang dihasilkan orang dan foto yang dihasilkan oleh peneliti sendiri, dan terakhir jenis data statistik digunakan untuk penelitian kualitatif, agar memberikan gambaran tentang kecenderungan subjek pada latar penelitian. Dari keempat jenis data tersebut di atas, jenis data yang paling dijadikan penelitian dari tulisan ilmiah ini adalah sumber tertulis.

\section{METODE YANG DigunAKAN}

Metode deskriptif kualitatif yaitu penggambaran atau pemberian makna secara sistematis, faktual dan akurat mengenai 
data. Sukmadinata (2003: 72), menjelaskan bahwa "penelitian dengan metode deskriptif ditujukan untuk mendeskripsikan atau menggambarkan fenomena-fenomena yang ada, baik fenomena yang bersifat alamiah ataupun rekayasa manusia."

Senada dengan pendapat di atas, Surahmad (1990: 134), menyatakan bahwa penyelidikan dengan metode deskriptif bertujuan untuk memecahkan masalah pada masa sekarang, di antaranya ada penyelidikan dengan penuturan, analisis, dan klasifikasi. Metode ini bisa juga disebut metode analisis.

Penggunaan metode deskriptif dengan pendekatan kualitatif dalam penilaian ini dipilih karena gejala-gejala informasi, peristiwa, keterangan-keterangan dari hasil pengamatan selama berlangsungnya proses penelitian mengenai "Implementasi Kebijaksanaan Reformasi Birokrasi dalam Penguatan Aparatur Sipil Negara di Kementerian Agama Republik Indonesia" ini, akan lebih tepat bila diungkapkan dalam bentuk kata- kata. Di samping itu data yang didapat lebih mendalam dan lebih sebenarnya. Data yang pasti yang merupakan suatu nilai di balik data yang tampak. Oleh karena itu dalam penelitian kualitatif tidak menekankan pada generalisasi, akan tetapi lebih menekankan pada makna.

\section{Populasi Penelitian}

Yang dimaksud subjek penelitian, adalah orang, tempat, atau benda yang diamati dalam rangka pembumbutan sebagai sasaran (Kamus Bahasa Indonesia, 1989: 862). Adapun subjek dalam penelitian ini, adalah Tim Reformasi Kementerian Agama Republik Indonesia, yang terdiri para pejabat/Pimpinan Tinggi Utama, Madya, dan Pratama di Kantor Pusat Kementerian Agama RI. Berdasarkan Keputusan Menteri Agama RI Nomor 196 Tahun 2014, sebagai berikut.

\section{Tim Reformasi Birokrasi} Kementerian Agama

\begin{tabular}{|c|c|c|}
\hline No & Tugas/Fungsi & Jumlah \\
\hline 1 & $\begin{array}{ll}\text { Tim } & \text { Pengelola/Pimpinan } \\
\text { Utama } & \end{array}$ & 3 \\
\hline 2 & $\begin{array}{l}\text { Tim Teknis/Pimpinan Utama } \\
\text { Madya }\end{array}$ & 4 \\
\hline 3 & $\begin{array}{l}\text { Sekreteriat Pengelola/ } \\
\text { Pimpinan Utama Pratama }\end{array}$ & 6 \\
\hline 4 & Tim Penilai Agen Perubahan & - \\
\hline 5 & Agen Perubahan & - \\
\hline 6 & $\begin{array}{l}\text { Tim Percepatan Reformasi } \\
\text { Birokrasi }\end{array}$ & ـ \\
\hline & Jumlah & 13 \\
\hline
\end{tabular}

Dengan rincian tugas, sebagai berikut.

1) Pimpinan Tinggi Utama, sebagai tim pengelola yang mempunyai tugas mengarahkan dan memantau pelaksanaan Reformasi Birokrasi;

2) Pimpinan Tinggi Utama Madya yang menjadi Tim Teknis pelaksanaan Reformasi Birokrasi; mempunyai tugas mengarahkan dan memantau pelaksanaan Reformasi Birokrasi Kementerian Agama

3) Pimpinan tinggi pratama sebagai personalia Sekretariat Pengelola bertugas membantu Tim Teknis Reformasi Birokrasi. (KMA No. 165 Tahun 2014).

Sumber data primer yang penulis teliti adalah Pimpinan Tinggi Utama 3 orang, 4 orang Pimpinan Tinggi Madya, dan 6 orang Pimpinan Tinggi Pratama pada Kantor Kementerian Agama.

Data sekunder adalah data-data yang didapat dari sumber bacaan dan berbagai macam sumber lainnya yang terdiri dari surat-surat pribadi, buku harian, notula rapat perkumpulan, sampai dokumen-dokumen resmi dari berbagai instansi pemerintah. Data sekunder juga dapat berupa majalah, buletin, publikasi dari berbagai organisasi, 
lampiran-lampiran dari badan resmi seperti kementerian-kementerian, hasil-hasil studi, tesis, hasil survei, studi histories, dan sebagainya.

Akan tetapi, jenis data data yang digunakan dalam penelitian ini, adalah data kualitatif, yaitu data yang tidak dapat dihitung (bukan berupa angka) dan diperoleh dalam bentuk informasi dari instansi maupun pihak-pihak lain yang ada kaitannya dengan masalah yang akan dibahas.

\section{Teknik Analisis Data}

Analisis data adalah proses mengorganisasikan dan mengurutkan data ke dalam pola, kategori dan satuan uraian dasar sehingga dapat ditemukan tema dan dapat dirumuskan hipotesis kerja seperti yang disarankan oleh data. Dari rumusan di atas dapatlah kita tarik garis besar bahwa analisis data bermaksud pertama-tama mengorganisasikan data.

Data yang terkumpul banyak sekali dan terdiri dari catatan lapangan, komentar peneliti, gambar, foto, dokumen berupa laporan, biografi, artikel, dan sebagainya. Setelah data dari lapangan terkumpul dengan menggunakan metode pengumpulan data di atas, maka peneliti akan mengolah dan menganalisis data tersebut dengan menggunakan analisis secara deskriptifkualitatif, tanpa menggunakan teknik kuantitatif.

Metode analisis pada penelitian ini menggunakan metode Analisis Asoca (Ability, Strength, Opportunities, Culture dan Agility). Suradinata (2014: 18) mengatakan bahwa "Untuk mengambil putusan yang strategis oleh mereka yang memiliki otoritas pemerintahan maupun organisasi sosial sebagai pengambil keputusan dan mereka yang melaksanakan penelitian baik secara kualitatif maupun kuantitatif setelah mempertimbangkan hasil analisis Asoca, dan faktor lainnya yang memerlukan kecerdasan dalam pengambilan putusan, dan mereka yang melakukan penelitian untuk memberikan hasil penelitiannya pada yang membutuhkan".

Metoda Analisis Asoca (Ability, Strength, Opportunities, Culture dan Agility). Ability adalah kemampuan, Strength adalah kekuatan, Opportunities adalah peluang, Culture adalah budaya dan Agility adalah kecerdasan.

Implementasi kebijaksanaan reformasi birokrasi dalam penguatan Aparatur Sipil Negara pada Kantor Kementerian Agama Republik Indonesia dapat didentifikasi dan dianalisis melalui analisis ASOCA, analisis ASOCA terbagi atas dua bagian yaitu analisis lingkungan internal dan analisis lingkungan eksternal, analisis lingkungan Internal antara lain:

a. Manajemen Sumber Daya Manusia
1. Tersedianya Dana Penunjang Kegiatan
2. Tersedianya Sarana dan Prasarana
3. Sistem Informasi
4. Capacity Building

b. Analisis lingkungan eksternal adalah peran institusi

1. SKPD yang berdaya saing

2. Teknologi

AnalisisASOCAdidalampenyelenggaraan implementasi kebijaksanaan dapat membantu pengalokasian; standar dan sasaran kebijaksanaan; sumber daya (manusia non manusia); hubungan antarorganisasi, karakteristik agen pelaksana; disposisi implementor ; dan kondisi lingkungan sosial, politik, dan ekonomi. Analisis di dalam program ini, dapat dilakukan dengan membuat matrik. Matriks ini terdiri dari sel-sel daftar kekuatan, kelemahan, peluang, ancaman di dalam penyelenggaraan program pemerintah untuk memperoleh mutu layanan yang baik.

Pada penelitian ini, analisis dilakukan terhadap sebuah kasus yang diteliti. 
Peneliti menganalisis hasil wawancara berdasarkan pemahaman terhadap halhal diungkapkan oleh responden. Data yang telah dikelompokkan tersebut oleh peneliti dicoba untuk dipahami secara utuh dan ditemukan tema-tema penting serta Kata kuncinya. Sehingga peneliti dapat menangkap pengalaman, permasalahan, dan dinamika yang terjadi pada subjek.

\section{HASIL PENELITIAN}

Reformasi Birokrasi adalah keniscayaan yang tak bisa ditawar-tawar lagi. Dalam melakukan reformasi birokrasi di Indonesia perlu adanya planned change, dan yang utama harus difokuskan dalam 3 (tiga) hal: pertama, komitmen dan dukungan dari pimpinan atau atasan (eselon I, II); kedua, bahwa bawahan (Eselon III, Staf ke bawah) merasa perlunya reformasi tersebut. Dan yang ketiga, bahwa para pimpinan seharusnya merupakan aktor utama sebagai pe-reform, sebelumnya tentunya dirinya sendiri merupakan bagian yang harus di-reform.

Ada beberapa langkah yang sudah dilaksanakan di Kementerian Agama Republik Indonesia dalam rangka reformasi birokrasi, langkah-langkah konkret dan taktis tersebut, antara lain:

1) Penataan organisasi, meliputi pemisahan, penggabungan/merger, penajaman tugas dan fungsi organisasi sehingga organisasi yang ada lebih efektif dan lebih efisien.

2) Penyempurnaan tata laksana (business process), meliputi pembuatan analisis dan evaluasi, analisis beban kerja, risiko jabatan, job description, serta sistem analisis kinerja aparatur sipil negara.

3) Peningkatan pelayanan publik, meliputi pembuatan standar pelayanan minimal, seperti standar biaya, mutu, waktu, sarana, prasarana, informasi dan teknologi yang kesemuanya sangat dibutuhkan dalam rangka perbaikan sistem pelayanan yang lebih terpadu.

4) Implementasi Sistem Akuntabilitas Kinerja Instansi Pemerintah (SAKIP), meliputi perumusan indikator kinerja utama sebagai tolok ukur keberhasilan capaian kinerja.

5) Pengembangan Sumber Daya Manusia (SDM) yang meliputi penyusunan formasi, rekruitmen, reposisi pegawai, penciptaan system assessment center, pembuatan Sistem Informasi Manajemen Kepegawaian (SIMPEG) yang terintegrasi, peningkatan koordinasi antar- unit terkait, pendidikan dan pelatihan (diklat) berbasis kompetensiserta peningkatan disiplin dan kinerja pegawai.

6) Penyusunan Standar Operasional Prosedur (SOP) untuk melaksanakan semua rangkaian kegiatan dari langkah-langkah konkret yang telah ditetapkan oleh Reformasi Birokrasi tersebut.

Analisis tata kelola pemerintahan yang baik di Indonesia perlu menggunakan metode Analisis Asoca (Ability, Strength, Opportunities, Culture dan Agility). Ability adalah kemampuan, Strength adalah kekuatan, Opportunities adalah peluang, Culture adalah budaya dan Agility adalah kecerdasan.

Analisis ASOCA akan diterapkan dalam menganalisis lebih jauh tentang strategi implementasi kebijaksanaan "Implementasi Kebijaksanaan Reformasi Birokrasi dalam Penguatan Aparatur Sipil Negara di Kantor Kementerian Agama Republik Indonesia", dengan harapan agar dapat ditemukan solusi untuk mengupayakan Aparatur Sipil Negara yang profesional, memiliki nilai dasar, etika profesi, bebas dari intervensi politik, bersih, jujur dan jauh dari praktik korupsi, kolusi dan nepotisme. 
Analisis lingkungan Internal antara lain sebagai berikut.

\section{Manajemen Sumber Daya Manusia}

Sebagaimana dikemukakan ahli manajemen bahwa manajemen sumber daya manusia tidak hanya sebagai seni dan ilmu pengetahuan, namun juga sebagai sebuah proses pembinaan terhadap sumber daya manusia yang berkelanjutan. Sebagai suatu profesi, kualitas Aparatur Sipil Negara (ASN) sedemikian rupa sangat dibutuhkan agar dapat mengelola suatu organisasi secara profesional dengan memahami secara komprehensif nilai-nilai (values), visi dan misi, aturan-aturan (rules), standardisasi (standardization), prosedur (prosedure) dan muatan lokal (local content) seperti budaya lokal dan perilaku organisasi yang berlaku dalam organisasinya. Kualitas sumber daya manusiadapatmenentukan keberhasilan sebuah organisasi. Aparatur Sipil Negara (ASN) yang profesional akan dapat tercipta melalui kegiatan dan program pembinaan dan reformasi yang terukur dan sistematis. Penguatan di bidang SDM menuntut dilakukannya penataan pegawai yang terstruktur dan komprehensif. Dengan dilaksanakannya penataan pegawai diharapkan dapat mewujudkan kesesuaian antara jumlah, komposisi dan kompetensi pegawai dengan kebutuhan organisasi dan optimalisasi kinerja birokrasi. Selain itu, dapat mengakselerasi penerapan manajemen kinerja dan meningkatkan kualitas pengembangan Sumber Daya Manusia (SDM). Sumber daya manusia yang baik memiliki kualifikasi penuh semangat, berilmu, tanggung jawab, profesional, berintegritas, rendah hati, memiliki etika dalam melakukan aktivitas, terus melakukan inovasi, terus mengembangkan diri, berjiwa melayani dan ikhlas beramal.
Bahwa segala sesuatu adalah anugerah Tuhan sehingga perlu menumbuhkembangkan ilmu secara selaras, menyerasikan keadilan untuk kemakmuran dan menciptakan pemerataan dalam keragaman yang sejahtera. Aparat yang baik harus menyadari bahwa masyarakat itu multi dimensi, sehingga perlu menjadi pengayom, pelindung serta membawa solusi bagi masyarakat. Aparatur sipil negara harus turut serta dalam upaya menjaga keseimbangan rohani dan jasmani dengan menumbuhkan rasa cinta, ketulusan, kebanggaan terhadap nusa dan bangsa. Aparatur sipil negara juga sebagai sumber daya manusia di bidang pemerintahan harus dinamis dalam keharmonisan, kuat, taat dan mandiri. Begitupun dalam melayani masyarakat, aparat sipil negara dituntut untuk memberikan layanan yang maksimal dan optimal sesuai dengan kebutuhan masyarakat.

2. Tersedianya Dana Penunjang Kegiatan

Tim reformasi birokrasi harus didukung oleh tersedianya anggaran. Anggaran Kementerian Agama Republik Indonesia adalah fasilitas utama dalam hal ini. Keberhasilan program/kegiatan yang dilakukan harus benar-benar terukur dan dapat di pertanggungjawabkan. Program dan kegiatan yang dilaksanakan oleh Kementerian Agama pada tahun 2017 mengacu pada program dan kegiatan yang tertuang pada rencana strategis (renstra) Kementerian Agama tahun 2015-2019. Penyesuaian/ pemutakhiran dilakukan pada level indikator Kinerja dan target kinerjanya.

\section{Tersedianya Sarana dan Prasarana}

Aparatur Sipil Negara membutuhkan sarana dan prasarana guna menunjang kegiatannya. Sarana dan prasarana ini membantu kelancaran tugas 
dan fungsi yang diembannya dalam melaksanakan Reformasi Birokrasi. Sarana dan prasarana juga menjadi alat untuk memudahkan terselenggaranya program pemerintahan yang baik oleh Aparatur Sipil Negara (ASN).

\section{Sistem Informasi;}

Dibutuhkan Aparatur Sipil Negara dalam memahami dan melaksanakan tugasnya secara terorganisir dan terukur. Sistem informasi ini juga membantu dalam menginventarisir dan mengevaluasi pelaksanaan Reformasi Birokrasi hingga dapat dievaluasi dampaknya terhadap peningkatan mutu dan pelayanan terhadap masyarakat. Sistem Informasi Manajemen Kepegawaian (SIMPEG) yang terintegrasi, peningkatan koordinasi antar- unit terkait. Sudah tetapi masih memerlukan pengelolaan yang lebih baik. Saat ini Kementerian Agama sedang membangun e-Gov untuk meningkatkan kualitas pengelolaan pelayanan berbasis elektronik. Untuk meningkatkan pelayanan publik Kementerian Agama sudah mempunyai Pelayanan Terpadu Satu Pintu (PTSP) di pusat dan Kanwil Kementerian Agama Provinsi. Targetnya pada tahun 2018 PTSP sudah berdiri di seluruh Kanwil Kementerian Agama Provinsi di Indonesia.

\section{Capacity Building;}

Proses evaluasi dan audit kinerja bisa dilakukan melalui peningkatan capacity building yang dilakukan pada program reformasi birokrasi di kementerian Agama Republik Indonesia. Kegiatan ini juga bertujuan membentuk character building bagi Aparatur Sipil Negara di kementerian Agama Republik Indonesia. Seperti diketahui bersama bahwa di dalam tubuh birokrasi dibutuhkan ASN yang loyal, disiplin, kerja keras dan tangguh dalam menghadapi tantangan.

\section{Komitmen Instansi/departemen;}

Kementerian Agama Republik Indonesia diharapkan berkomitmen untuk senantiasa menetapkan dan merancang kegiatan reformasi birokrasi yang berkelanjutan, terus-menerus dan dilakukan menyeluruh untuk semua lingkup yang ada di Kementerian Agama Republik Indonesia.

\section{Program Kerja;}

Kementerian Agama Republik Indonesia harus memiiki program kerja yang jelas dalam kegiatan reformasi birokrasi yang terencana, lebih terarah, terutama dalam menggunakan sumber daya baik berupa dana, tenaga kerja maupun sarana dan prasarana secara efektif dan efisien guna mencapai tujuan penguatan Aparatur Sipil Negara secara maksimal. Melalui program kerja kita dapat mengetahui dan mengerti visi dan misi serta arah kebijaksanaan yang akan dilakukan sesuai tugas pokok dan fungsi dari anggaran yang ditetapkan.

Adapun analisis lingkungan eksternal adalah:

\section{Peran Institusi;}

Kementerian Agama RI adalah institusi yang masih bersifat sentralistik. Peran yang bersifat sentralistik ini memungkinkan terjadinya kontrol dan monitoring yang lebih baik, terarah dan terukur. Tapi potensi sentralistik ini juga bisa memungkinkan terjadi praktik disharmoni dan tidak sinkronnya antara program pusat dan daerah. Biasanya karena sifatnya sentralistik, sehingga terlihat kurang mengakomodasikan nilai efisiensi dan efektivitas dalam pencapaian tujuan organisasi dari masing-masing instansi baik di pusat maupun daerah. 


\section{ASN yang berdaya saing;}

Adanya peluang dukungan dan persamaan persepsi, visi dan misi serta tujuan dari pelaksanaan reformasi birokrasi di lingkungan Kementerian Agama dalam meningkatkan kapasitas dan kinerja pegawainya dihadapkan pada kendala yang timbul, yaitu masih rendahnya pemahaman tupoksi dan wawasan serta kesadaran dari pegawai dalam mendukung pelaksanaan tugas. Bahwa budaya birokrasi masih dianggap lemah dan cenderung statis. Berbagai tulisan dan kajian yang mengangkat tentang keberadaan organisasi publik baik yang menyoroti dari sisi budaya, layanan maupun kinerja Aparatur Sipil Negara secara umum menunjukkan budaya organisasi publik belum mendukung terhadap pelaksanaan tugas dan pelayanan yang diberikan oleh Aparatur Sipil Negara (ASN). Kajiankajian yang dilakukan hampir tidak pernah mengangkat tentang budaya yang mendukung terhadap pelaksanaan tugas yang diemban oleh organisasi pemerintah. Untuk mendukung pelaksanaan tugas-tugas yang ada setiap pegawai harus senantiasa memiliki pemahaman yang baik terhadap apa yang telah menjadi tugas dan fungsinya. Aparatur Sipil Negara diharapkan memiliki daya saing yang tinggi dalam melaksanakan tugas dan fungsinya dalam memberikan pelayanan optimal bagi masyarakatnya.

\section{Faktor teknologi;}

Perubahan yang semakin cepat di era global dan era digital di dunia ini membuat pesatnya pertumbuhan dan perkembangan serta pembangunan di bidang informasi dan teknologi sampai pada perkembangan cyber security dan juga perkembangan sistem keamanan dan pertahanan 'dunia maya' terus akan mengalami perkembangan seperti serangan peretas/hacker yaitu serangan terhadap situs dan sistem yang dikendalikan oleh Kementerian Agama Republik Indonesia. Dalam upaya pelayanan pemerintah yang lebih baik, cepat dan tepat kepada masyarakat diperlukan keterampilan dan penguasaan teknologi informasi oleh Aparatur Sipil Negara yang ada di Kementerian Agama RI. Namun pencegahannya harus terus diakukan agar tidak terganggu oleh serangan peretas atau tracker/hacker. Data yang dikelola termasuk dalam hal yang bersifat rahasia harus dijaga betul supaya kita tidak kecolongan. Begitupun sistem navigasi terhadap sistem informasi harus ter-update dan terus mengikuti perkembangan teknologi yang terbaru.

Ada beberapa Kata kunci dalam konsep dan Implementasi Kebijaksanaan Reformasi Birokrasi dalam Penguatan Aparatur Sipil Negara Kementerian Agama RI dalam penelitian ini antara lain:

1. Keuletan yang merupakan kualitas diri Aparatur sipil Negara (ASN).

2. Ketangguhan Aparatur Sipil Negara adalah kualitas yang menunjukkan kekuatan atau kekokohan sebagaimana dipersepsikan dari luar oleh pihak lain.

3. Ancaman merupakan hal atau usaha yang bersifat mengubah kebijaksanaan dan dilaksanakan secara konsepsional kriminal serta politis.

4. Tantangan merupakan usaha yang bertujuan atau bersifat menggugah kemampuan Aparatur Sipil Negara (ASN).

5. Hambatan merupakan usaha yang bertujuan melemahkan Aparatur Sipil Negara (ASN) secara tidak konsepsional yang berasal dari diri sendiri.

6. Gangguan adalah hambatan yang berasal dari luar yang bertujuan melemahkan 
Aparatur Sipil Negara (ASN) dengan cara tidak konsepsional.

7. Identitas adalah ciri khas atau karakter Aparatur Sipil Negara (ASN) jika dilihat secara keseluruhan yang membedakannya dengan yang lain.

8. Integritas adalah satu kesatuan yang menyeluruh dalam kehidupan nasional suatu bangsa, baik aspek alamiah maupun aspek sosial kemasyarakatan.

Dalam menggunakan metode analisis ASOCA kita terlebih dahulu harus mengetahui faktor-faktor yang menjadi bagian dari masing-masing unsur ASOCA antara lain;

\section{Ability (kemampuan)}

2. Strength (kekuatan)

3. Opportunities (peluang)

4. Culture (budaya)

5. Agility (kecerdasan).

Analisis ini selanjutnya diidentifikasi dari masing-masing faktor lingkungan baik internal maupun eksternal, selanjutnya diklasifikasi berdasarkan unsur-unsur ASOCA. Faktor internal yang sangat berpengaruh dalam kegiatan ini adalah meningkatnya kualitas sumber daya manusia dalam hal ini ASN yang memiliki kompetensi yang lebih baik dari sebelumnya sehingga pelaksanaan reformasi birokrasi secara tidak langsung diharapkan dapat meningkatkan kinerja Aparatur Negeri Sipil (ASN). Dalam observasi yang dilakukan oleh peneliti, kinerja organisasi yang optimal sangat ditentukan oleh kemampuan sumber daya manusia dalam hal ini Aparatur Sipil Negara (ASN). Jadi reformasi birokrasi seyognyanya memacu kemampuan ASN untuk dapat memiliki hal-hal yang oleh Ermaya dikenal dengan rumus 9C sebagai berikut.

1. Kepedulian terhadap tugas (care).

2. Membawa kepedulian pada hasil kerja yang baik (carry)

3. Bekerja hati-hati (carefull)

4. Di bidangnya karena kecerdasan

\section{(capable)}

5. Dilakukan dengan bersih tanpa korupsi, kolusi dan nepotisme (clean)

6. Pekerjaan merupakan budaya yang baik (culture)

7. Menghormati dan menguasai karakteristik moral dan etika (caracter)

8. Pekerjaannya merupakan karier dan diakukan secara ikhlas sebagai pengabdian (carier)

9. Integritas yang tinggi (clear)

Untuk mewujudkan pelayanan yang memiliki transparansi, akuntabilitas dan responsibilitas dari ASN, tentunya pengelolaan sumber daya manusia menjadi sangat esensial, karena merupakan subjek dari kegiatan yang ada dan pengelola faktor kemampuan lainnya. Oleh karena itu, wajar apabila pemerintah memberikan perhatian yang serius pada upaya peningkatan kinerja pegawainya dalam melakukan pelayanan publik.

Kendala dan hambatan dalam perjalanan Reformasi Kementerian Agama tahun 2016 kami inventarisir dari laporan tahunan Reformasi Birokrasi tahun 2016 Kementerian Agama RI. Data ini menunjukkan adanya beberapa kendala dan hambatan, walaupun demikian secara umum pelaksanaan program dan kegiatan dapat dilaksanakan, meskipun masih belum sesuai yang ditargetkan. Kendala dan hambatan tersebut antara lain:

1. Masih kurangnya komitmen pimpinan terhadap pelaksanaan reformasi birokrasi Kementerian Agama. Unsur ini merupakan salah satu hal terpenting yang menjadi kendala dalam implementasi reformasi birokrasi. Kuatnya komitmen dan kepemimpinan politik untuk merubah paradigma birokrasi akan menentukan keberhasilan reformasi birokrasi ini. Inti dari komitmen pimpinan dalam reformasi birokrasi seharusnya bukan 
sekedar wacana/jargon saja, namun harus benar-benar terwujudkan.

2. Penentangan (resistensi) dari dalam birokrasi itu sendiri. Poin ini merupakan salah satu kendala sekaligus tantangan dalam suksesnya pelaksanaan reformasi birokrasi. "Kenyamanan" yang dirasakan selama ini oleh jajaran birokrat (status quo) membuat mereka sulit untuk merubah pola pikir maupun sikap mental untuk mendukung ke arah perubahan yang lebih baik. Intinya terjadi penentangan oleh pihak internal (birokrat itu sendiri) terhadap usaha perubahan yang menjadi inti dari reformasi birokrasi. Ketidakinginan untuk merubah pola pikir termasuk budaya kerja dari para birokrat yang ada tentunya menjadi kendala dalam perubahan itu sendiri. Faktor inilah yang merupakan hal krusial dalam implementasi reformasi birokrasi di Indonesia secara menyeluruh.

3. Program dan kegiatan Reformasi Birokrasi Kementerian Agama belum banyak atau belum memadai anggarannya.

4. Banyaknya jumlah lembaga pada kementerian agama. Berdasarkan data kelembagaan biro organisasi dan tata laksana jumlah lembaga sampai dengan desember 2016 adalah sebanyak 10.249 lembaga.

5. Jumlah pegawai yang besar dan kompetensi SDM yang belum memadai. Berdasarkan data Simpeg biro Kepegawaian per Desember 2016, jumlah PNS Kementerian Agama sebanyak 231.233 orang.

6. Infrastruktur Teknologi Informasi dan komunikasi kurang memadai.

7 Masih kurangnya penguatan ketatalaksanaan.

8. Lemahnya kordinasi antar- unit organisasi.

9. Sosialisasi Reformasi Birokrasi yang kurang kepada satuan kerja di daerah, terutama yang terkait dengan penginternalisasian Road Map Reformasi Birokrasi Kementerian Agama 20152019.

10. Pelaksanaan mekanisme penghargaan dan sanksi (reward and punishment) belum berjalan.

Berdasarkan hal di atas, dapat dirumuskan sebuah model pengembangan dan akselerasi faktor determinan dalam akselerasi implementasi kebijaksanaan reformasi birokrasi di Kementerian Agama Republik Indonesia yang dapat dilihat pada gambar di bawah ini:

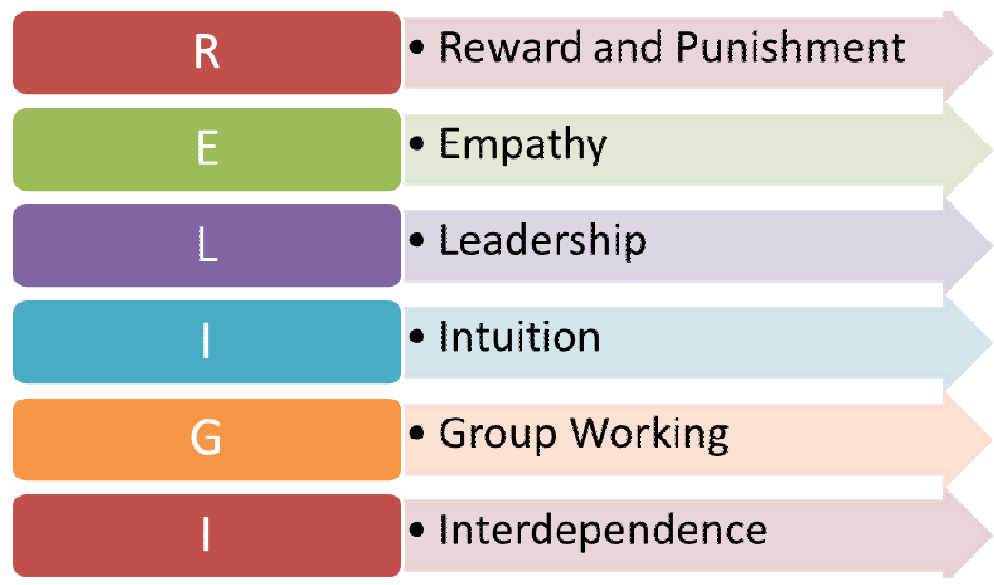

Model akselerasi Implementasi Kebijaksanaan Reformasi Birokrasi di Kementerian Agama Republik Indonesia 
Berdasarkan analisis lingkungan dengan menggunakan instrumen ASOCA di atas, maka ditemukan isu-isu yang perlu menjadi perhatian yaitu 1) sikap indisipliner pegawai di lingkungan Kementerian Agama Republik Indonesia dengan adanya kebijaksanaan reformasi birokrasi belum menunjukkan perubahan yang signifikan sebagaimana ditemukan pada penelitian membutuhkan extra attention dari pimpinan dalam bentuk hukuman dan penghargaan (reward and punishment).

Penghargaan yang diberikan dapat berupa penghargaan individu (fisik dan non fisik) dan penghargaan kelompok kerja; 2) kebijaksanaan reformasi birokrasi yang telah berjalan sesuai dengan roadmap RB di Kementerian Agama saat ini masih didominasi oleh peran agen perubahan sehingga dibutuhkan dukungan psikologis baik baik dari pimpinan maupun teman sejawat (empathy). Empathy dapat berupa kerja sama, komunikasi, sukarela dan adaptasi; Operasionalisasi kebijaksanaan reformasi birokrasi melalui aksi dan sikap dalam melaksanakan kebijaksanaan operasional tidak terlepas dari peran dan figur pimpinan dari setiap organisasi di lingkungan Kementerian Agama (leadership). Kepemimpinan dalam organisasi dapat dilihat dari sikap, pelibatan diri, dan mengarahkan bawahan; 4) Aspek sosial khususnya dalam pelayanan publik, adanya stigma negatif dari masyarakat sebagaimana diungkapkan di atas, mengakibatkan dibutuhkannya profil pegawai yang mampu memahami kondisi pengguna layanan baik itu psikologi maupun teknis (Intuition). Intuisi dapat dilihat dari adanya respons dari penyedia layanan, keterampilan, dan penampilan; Adanya resistensi atau penentangan dari dalam kelompok atau unit organisasi sendiri terhadap keberadaan agen perubahan menuntut pimpinan harus mengedepankan kerja sama (group working). Kerjasama dalam grup dapat dilihat dari aspek konsistensi kerja dan kemampuan untuk dapat dipercaya. Sementara di sisi lain, agar tidak menurunkan semangat agen perubahan sehingga dengan hal tersebut akan bermuara pada lahirnya sikap saling ketergantungan antara satu pegawai dengan pegawai lainnya (Interdependence).

\section{SIMPULAN DAN SARAN}

\section{SiMPULAN}

Berdasarkan hasil penelitian dan pembahasan Implementasi Kebijaksanaan Reformasi Birokrasi dalam Penguatan Aparatur Sipil Negara di Kementerian Agama, maka dapat dibuat simpulan model akselerasi implementasi kebijaksanaan reformasi birokrasi dalam penguatan ASN di Kementerian Agama Republik Indonesia adalah dengan mengadaptasi RELIGI (Reward and Punishment, Empathy, Leadership, Intuition, Group Working, and Interdependence).

\section{SARAN}

Saran peneliti dalam Implementasi Kebijaksanaan Reformasi Birokrasi dalam Penguatan Aparatur Sipil Negara di Kementerian Agama adalah Model akselerasi Implementasi Kebijaksanaan Reformasi Birokrasi Birokrasi dalam Penguatan Aparatur Sipil Negara di Kementerian Agama Republik Indonesia adalah RELIGI perlu dimulai dengan melakukan hal-hal sebagai berikut

a) Revisi komitmen budaya kerja Kementerian Agamayangmengakomodir pelaksanaan kegiatan lintas bimas;

b) Agar memperlancar komunikasi dan koordinasi dalam rangka percepatan reformasi birokrasi dalam penguatan Aparatur Sipil Negara, selain sumber daya keuangan dan sumber daya manusia, tetapi juga dibutuhkan sumber daya kewenangan melalui revisi tugas pokok dan fungsi sebagai dasar bertindak sebuah organisasi. 


\section{DAFTAR PUSTAKA}

Bintoro Tjokroamidjojo. 2000. Good Governance, Paradigma Baru Manajemen Pembangunan. Jakarta: UI Press.

Edward III. 1980. Implementation Public Policy. Washington DC: Congresional Quarter Press.

Fuad, Noor \& Ahmad, Gofur. 2009. Integrated HRD. Jakarta: Grasindo.

Harbani, Pasolong.2008.Kepemimpinan Birokrasi. Bandung: CV.Alfabeta.

Kartono, Kartini. 2006. Pemimpin dan Kepemimpinan, Apakah Kepemimpinan Abnormal Itu? Jakarta: PT. Raja Grafindo Persada

Kristiadi. 1996. Kepemimpinan. Jakarta: LAN RI

Lippit, R. J. W, and B. Westley. 1956. The Dynamics of Planned Change, Harcourt. New York: Brace and World, Inc.

Loina Lalolo Krina P, 2003. Indikator \& Alat Ukur Prinsip Akuntabilitas, Transparansi \& Partisipasi.Jakarta: Sekretariat Good Public Governance Badan Perencanaan Pembangunan Nasional.

Mangkunegara, A. A. P. 2000. Manajemen Sumber Daya Manusia. Bandung: PT. Remaja Rosda Karya.

Masaong, Kadim dan Arfan A. Tilomi. 2011. Kepemimpinan Berbasis Multiple Intelligence. Bandung: Alfabeta.

Michael G. Roskin, 2005. Political Science: An Introduction New York: Prentice Hall

Moh. Nazir. 2003. Metode Penelitian. Jakarta: PT. Ghalia Indonesia.

Moleong, Lexy J. 2008. Metode Penelitian Kualitatif. Bandung: CV. Remaja Rosdakarya.
Nawawi, Hadari. 2006. Manajemen Strategik Untuk Organisasi Non-Profit. Yogyakarta: Gajah Mada University Press.

Osborne, David and Peter Plastrik. 2010. Memangkas Birokrasi. Jakarta: PPM Bisnis.

Rusdiana, A \& Ghozhin. 2014. Manajemen Berwawasan Global. Bandung: Pustaka Setia.

S. Nasution. 2004. Metode Research. Jakarta: Bumi Aksara

Salusu, J. 1996. Pengambilan Keputusan Stratejik. Jakarta: Gramedia Pustaka Utama.

Siagian. P. Sondang. 2002. Kiat Meningkatkan Produktivitas Kerja. Jakarta.

Spencer, Lyle M. \& Signe M. Spencer. 1993. "Competence at Work: Models for Superior Performance". New York: John Wiley \& Sons, Inc.

Subarsono, A. G. 2008. Analisis Kebijakan Publik (Konsep, Teori dan Aplikasi). Cetakan Ketiga. Pustaka Pelajar: Yogyakarta.

Sugiyono. 2006. Metode Penelitian Administrasi. Bandung: CV.Alfabeta.

Suradinata Ermaya. 2014. Analisis Kepemimpinan, Strategi Pengambilan Keputusan. Bandung: Alqaprint Jatinangor

Sutarto. 2006. Dasar-dasar Kepemimpinan Administrasi. Cetakan Ketujuh. Yogyakarta Gadjah Mada University Press.

Syafri, Wirman. 2010. Kuliah Umum: Tinjauan Empirik dan Perspektif Model Peningkatan Kinerja Aparatur Negara. Rangkasbitung: STISIP Setiabudhi. 